\title{
Invasive North American bullfrogs transmit lethal fungus Batrachochytrium dendrobatidis infections to native amphibian host species
}

4

5 6

$9 \quad$ Claude Miaud

10 Université de Savoie-Mont-Blanc, UMR CNRS 5553, Laboratoire d'Écologie Alpine, 73376 11 Le-Bourget-du-Lac, France

12 Centre d'Ecologie Fonctionnelle et Évolutive (UMR 5175), Ecole Pratique des Hautes 13 Etudes, Biogéographie et Ecologie des Vertébrés, Campus CNRS, 34293 Montpellier, France 14 e-mail: claude.miaud@cefe.cnrs.fr

15 Tél: 33467613343

16

\section{Tony Dejean}

Université de Savoie-Mont-Blanc, UMR CNRS 5553, Laboratoire d'Écologie Alpine, 73376 Le-Bourget-du-Lac, France

Parc naturel régional Périgord-Limousin, 24450 La Coquille, France

tony.dejean@spygen.com

Karine Savard

Université de Savoie-Mont-Blanc, UMR CNRS 5553, Laboratoire d'Écologie Alpine, 73376 Le-Bourget-du-Lac, France

Agriculture and Agri-Food Canada, Ottawa, Ontario K1A 0C6, Canada karine.savard@agr.gc.ca

Annie Millery

Université de Savoie-Mont-Blanc, UMR CNRS 5553, Laboratoire d'Écologie Alpine, 73376 Le-Bourget-du-Lac, France

Annie.Millery@univ-savoie.fr

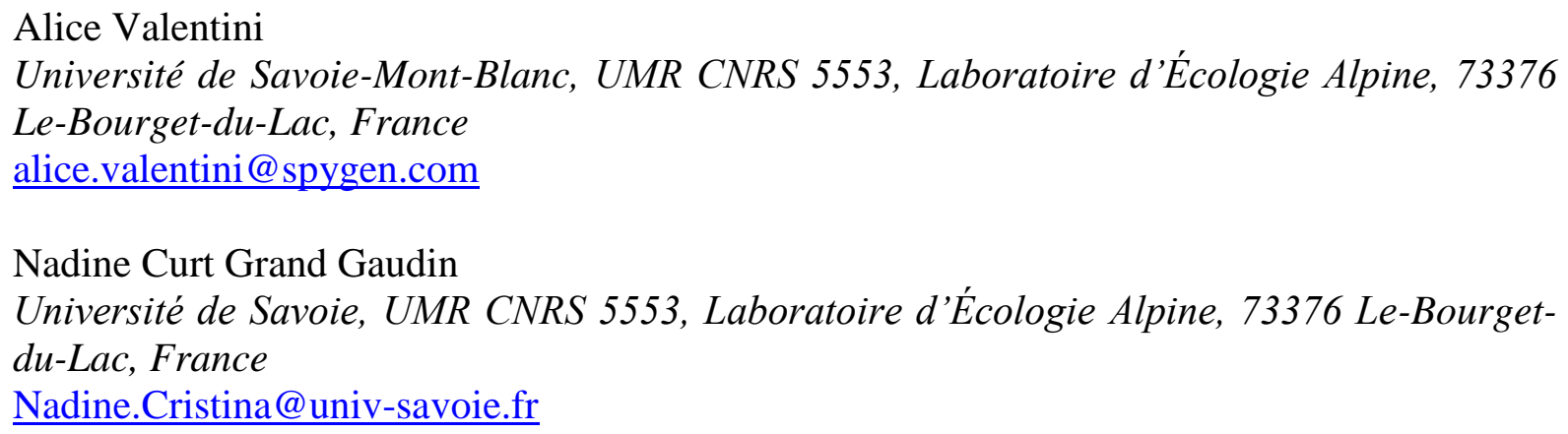


2 Trenton W.J. Garner

3 Institute of Zoology, Zoological Society of London, Regents Park, NWI 4RY, London, UK

4 Environmental Sciences and Development, Northwest University, Private Bag X6001,

$5 \quad$ Potchefstroom, 2531, South Africa

$6 \quad$ Trent.Garner@ioz.ac.uk

8 Abstract Invasive species can be a threat to native species in several ways, including

9 transmitting lethal infections caused by the parasites they carry. However, invasive species

10 may also be plagued by novel and lethal infections they acquire when invading, making

11 inferences regarding the ability of an invasive host to vector disease difficult from field observations of infection and disease. This is the case for the pathogenic fungus

Batrachochytrium dendrobatidis $(\mathrm{Bd})$ in Europe and one invasive host species, the North

American bullfrog Lithobates catesbeianus, hypothesized to be responsible for vectoring lethal infection to European native amphibians. We tested this hypothesis experimentally using the alpine newt Ichthyosaura alpestris as our model native host. Our results show that infected bullfrog tadpoles are effective vectors of Bd. Native adult newts co-housed with experimentally infected bullfrog tadpoles became Bd infected (molecular and histological tests). Moreover, the exposed adult newts suffered mortality while the majority of infected Bullfrog tadpoles survived until metamorphosis. These results cannot resolve the historical role of alien species in establishing the distribution of Bd across Europe or other regions in the world where this species was introduced, but they show its potential role as a Bd reservoir capable of transmitting lethal infections to native amphibians. Finally, our results also suggest that the removal of infected bullfrogs from aquatic environments may serve to reduce the availability of Bd in European amphibian communities, offering another justification for bullfrog eradication programmes that are currently underway or may be considered. 
1 Keywords Introduced amphibian $\bullet$ disease $\bullet$ cross-contamination $\bullet$ fungus $\bullet$ American 1 22 bullfrog Alpine newt 


\section{Introduction}

2

3 Invasive, non-native species are considered to be one of the greatest threats to biodiversity

4 and threaten native species through a variety of mechanisms. The co-introduction of parasites

5 capable of eliciting significant pathogenesis in naïve native hosts is thought to be one of the

6 major mechanisms behind biodiversity loss attributable to invasive species (Daszak et al.

7 2000; Prenter et al. 2004; Crowl et al. 2008). Indeed, parasites that are transported with

8 invasive species tend to reach equivalent prevalence in native species (Torchin et al. 2003),

$9 \quad$ sometimes with devastating consequences (Martel et al. 2014; Doddington et al. 2013; Bosch et al. 2013). However, invasive species may carry significantly reduced parasite diversity when invading (Torchin et al. 2003) and commonly become infected with parasites that occur in endemic residents (Colautti et al., 2004; Bürgi and Mills 2014). Invasive species that are infected with resident parasites can suffer costs exceeding those experienced by the native host species (Wolfe et al. 2004) or equivalent to those experienced by native species infected with newly introduced parasites (Heger and Jeschke 2014). The unpredictability of these relationships means that patterns of parasite infection and disease in native and invasive hosts do not always indicate which host may be serving as a vector for the parasite.

Batrachochytrium dendrobatidis (Bd), a global fungal pathogen of amphibians, is presumed to be an invasive parasite in many parts of its range (Farrer et al. 2011). Bd invasion is commonly attributed to the release of infected, asymptomatic species that have been displaced as a result of trade (Hanselmann et al. 2004). A prime example is that of the North American bullfrog Lithobates catesbeianus (Hanselmann et al. 2004). Due to their ubiquity as a traded species infected with Bd (Bai et al. 2010; Schloegel et al. 2009), their distribution and a consistent pattern of infection with Bd (Garner et al. 2006), they have been proposed to be important vectors of Bd into native amphibians. Bullfrogs may contribute to 
1 maintain Bd in native amphibian community (Peterson and McKenzie 2014), whereas the

2 distribution of invasive bullfrogs appears as a poor predictor of Bd distributions (Richardson

3 et al. 2014; Bataille et al. 2013). Native bullfrogs do have the ability to transmit infection to

4 species that occur within their natural range (Greenspan et al. 2012), invasive bullfrogs

5 tended to produce a higher number of Bd zoospores relative to native species (Peterson and

6 McKenzie 2014) but do not appear to sustain infections for prolonged periods of time and can

7 die from heavy infections (Gervasi et al. 2013). The evidence that invasive bullfrogs can act

8 as significant vectors of chytridiomycosis to native hosts is relatively weak.

Bullfrogs have been widely introduced in Europe in an uncoordinated, multinational

10 effort to establish viable populations for the trade in frog legs (Ficetola et al. 2007). Invasive 
1 amphibians would be susceptible to lethal chytridiomycosis caused by transmission from

2 infected bullfrogs, while bullfrogs would not exhibit significant costs associated with

3 exposure to and infection with $\mathrm{Bd}$.

In this paper, we experimentally determine if invasive bullfrogs are significant vectors

5 of Bd to European amphibians. We cohoused experimentally infected bullfrog tadpoles with

6 adult native amphibians, in this case, the alpine newt. We selected the alpine newt because it

7 is known to be infected with Bd across Europe (Zampiglia et al. 2013; Sztatecsny and Glaser

8 2011) but little is known about its susceptibility to lethal chytridiomycosis. We considered

9 bullfrog tadpoles as the appropriate life history stage for assessing reservoir status of the

10 species because tadpoles with prolonged larval periods are commonly cited as significant reservoirs of infection (Briggs et al. 2010; Walker et al. 2010). We recorded infection status, determined through molecular diagnostics and histology, burden of infection and survival in

both bullfrog tadpoles and adult alpine newts. For bullfrogs, we measured mortality rates until the onset of metamorphosis, as significant costs associated with larval infection initially manifest when metamorphosis is near to completion (Gervasi et al. 2013; Walker et al. 2010; 16 Garner et al. 2009).

\section{Materials and methods}

One clutch of American bullfrog (Lithobates catesbeianus) spawn was collected in June 2009

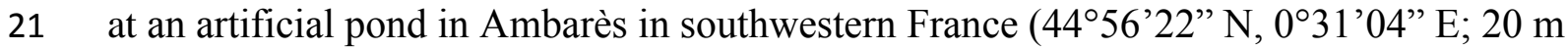

22 a.s.1.). Eggs were hatched and larvae reared in the laboratory in three plastic containers $(400 \mathrm{x}$

$23600 \times 200 \mathrm{~mm}$ ) each containing approximately $35 \mathrm{~L}$ of aged tap water. Larvae were fed

24 flaked goldfish food provided ad libitum during this and the subsequent exposure periods (see 
1 were selected randomly and examined for evidence of infection by swab-sampling their

2 mouthparts (swab ref. M01-MW100, Kitvia Co.) and testing DNA extracted from these

3 swabs using the TaqMan Assay described by Boyle et al. (2004). Because the extraction

4 reagent is a PCR inhibitor, samples were diluted by a ratio of 1:10 prior to attempted PCR

5 amplification. For all molecular assessments of infection, amplifications yielding quantitative

6 scores of 0.1 genomic equivalents (GE; untransformed value) or greater were considered Bd-

7 positive, allowing us to assign individuals as either 'infected' or 'not infected'.

Twenty tadpoles were transferred to plastic containers $(240 \times 160 \times 144 \mathrm{~mm})$ filled

9 with approximately $2 \mathrm{~L}$ of aged tap water and maintained as such until the end of the 
1 aged tap water. Ten of these experimental units were left as is, containing only a single newt.

2 We added 3 bullfrog tadpoles to all of the other 30 replicates; 10 with unexposed and

3 presumably uninfected tadpoles, and 20 with exposed and presumably infected tadpoles.

4 Tadpoles and newts were cohoused for 15 days at $20.1 \pm 1.0^{\circ} \mathrm{C}$ and on a $16 \mathrm{hr} / 8 \mathrm{hr}$ artificial

5 day/night schedule. Water levels were assessed daily and topped up when needed with aged

6 tap water. On day 15, tadpoles were removed, water levels reduced by $500 \mathrm{~mL}$ and containers

7 tilted to allow newts to have access to a terrestrial area (a plastic box, $140 \times 140 \mathrm{~mm}$, placed

8 within the experimental unit). While cohoused with tadpoles and during the post-exposure

9 period, newts were fed chironomid larvae every 48 hours. Newt containers were cleaned

10 every day with a disposable, sterile plastic pipette to remove feces and food remains. For 29 days after tadpoles were removed we recorded newt mortality and all newts were again swab sampled after death or as survivors at the end of the experiment. Tadpoles that were cohoused with newts ( 1 per replicate involving exposed tadpoles, $n=30$, and 2 per unexposed tadpoles. Tadpoles were maintained as such until the onset of metamorphosis (Gosner stage 42; Gosner 1960) and then swab-sampled across the epidermis for evidence of infection. We switched swab sampling to skin at this stage because tadpoles have shed keratinized mouthparts which are the target of infection earlier in development, and because keratinization of the stratum corneum that occurs at this time becomes the new target for $\mathrm{Bd}$ infection.

Dead newts were stored in $70^{\circ}$ alcohol. The four newts exposed to $\mathrm{Bd}$ infected bullfrog tadpoles alive at the end of the experiment were sacrificed with an overdose of $10 \mathrm{~mL} / \mathrm{L}$ of phenoxyethanol. Ten cross sections $(4 \mu \mathrm{m})$ were taken from skin sampled from the interior proximal part of the hind foot of each newt. The skin was embedded in tissue-teck (Sakura Fineteck, USA) and frozen at $-18^{\circ} \mathrm{C}$. Cross sections were cut using a LEICA CM3050 S 
1 freezing microtome, stained with Ehrlich's haematoxylin and examined for evidence of

2 infection with Bd using light microscopy.

3 Statistical analyses were performed with the Program R (R Development Core Team, 4 2010). We used log rank tests to test for differences amongst treatment groups for both 5 bullfrog tadpoles and alpine newts. We also assessed the differences in alpine newt mortality 6 between the 3 treatments using survival analysis (Kaplan-Meier estimate) with 'time until 7 death' as the response variable. Individuals without a corresponding time until death (i.e., 8 survived to the end of the experiment, $\mathrm{n}=23$ ) were removed from the analysis.

\section{Results}

12 Bullfrog tadpole Bd status and survival

14 The 30 tadpoles from which unexposed tadpoles were selected for cohousing with newts

$15(\mathrm{n}=10)$ tested negative for Bd DNA (Table 1). The 60 tadpoles experimentally exposed to $\mathrm{Bd}$ 16 zoospores were comprehensively infected with Bd (mean GE \pm 1 SD: $58.6 \pm 32.8$ ) at the start

17 of the cohousing period with newts $(n=20$, table 1). Exposed tadpoles that were removed 18 from experimental replicates all tested positive for infection on day $15(\mathrm{n}=60$, mean $\mathrm{GE} \pm 1$

19 SD: $39.6 \pm 23.3$ ), while those from unexposed replicates did not test positive. Twenty of the

2026 tadpoles from the exposed replicates surviving to the end of the experiment also tested

21 positive $(n=20$, mean GE \pm 1 SD: $49.7 \pm 29.3)$, whereas no unexposed tadpoles tested 22 positive on day 44.

23 Tadpoles started to metamorphose (Gosner stage 42) on day 70. Only seven tadpoles 24 did not survive to this date, among them 4 exposed to Bd and cohoused with alpine newt, 2 unexposed to Bd and cohoused with alpine newt, and 1 control (unexposed to Bd and alone). 
1 Survival of bullfrog tadpoles did not differ across tadpole treatment groups (20 tadpoles

2 housed alone and the two newt experiment treatments: Fig. 1a; Log rank test, Chi square test

$3=1.3, \mathrm{df}=2, p=0.526)$.

4

$5 \quad$ Alpine newt Bd status and survival

6

7 All 40 male alpine newts tested negative for Bd before cohousing (Table 1). Newts housed

8 alone $(n=10)$ or with unexposed bullfrog tadpoles $(n=10)$ for 15 days tested negative for $B d$ at

9 the end of the experiment. Alternatively, 14 newts cohoused with infected bullfrog tadpoles

10 tested positive for infection either at time of death or at the end of the experiment (mean GE

$11 \pm 1$ SD: $7.6 \pm 6.2$ ). The remaining 6 newts cohoused with infected bullfrog tadpoles tested bullfrog tadpoles which died during the experiment, 11 tested PCR positive for infection. Of the 4 newts cohoused with infected bullfrog tadpoles that survived, 3 were positive for Bd (respectively 3.15, 4.4 and $46.4 \mathrm{GE}$ ).

Histological examinations were performed on the skin of all the newts which were exposed to infected bullfrog tadpoles (16 dead newts and the 4 newts alive at the end of the experiments, table 1). Intracellular thalli and zoosporangia at various stages of maturation were observed in the 11 newts that died and tested PCR positive for Bd, in 3 of the 5 dead newts that tested PCR negative for Bd, and in the 3 newts PCR positive for Bd which survived to the end of the experiment. One newt that survived and PCR tested negative for Bd also had no observable thalli and zoosporangia.

Significant variation of mortality occurred among newt treatments: 16 of 20 newts exposed to Bd-infected bullfrog tadpoles were dead by the end of the experiment, while only one of the 20 newts that were not exposed to Bd or tadpoles died. Newts began dying on day 
126,9 days after bullfrog tadpoles were removed (Fig. 1b). Cohousing newts with infected

2 tadpoles significantly affected the mortality rate (Log rank test, Chi square $=21.7, \mathrm{df}=2, p=$

$\left.31.91 \times 10^{-05}\right)$. At day 30, survival of newts cohoused with infected tadpoles was reduced by

$425 \%$ when compared to newts cohoused with uninfected tadpoles or newts reared alone

5 (Table 2). At day 38, survival of newts cohoused with infected tadpoles was reduced by $80 \%$

6 compared to newts cohoused with uninfected tadpoles and $70 \%$ compared to those reared

7 alone (Table 2).

8

9 Discussion

10

Genetic and genomic data have been used to describe geographically widespread Bd and endemic Bd lineages (Farrer et al. 2011; 2013). The contact between allopatric populations of Bd could allow recombination, generation of virulent lineages and lead to contemporary amphibian disease emergence (Farrer et al. 2011). Increased sampling and analysis confirmed that Bd is composed of multiple divergent lineages, but which appear endemic in some parts of its range and novel (i.e. emerging) in others (Rosenblum et al. 2013). Perhaps more relevant to this study, patterns of mutation, recombination and aneuploidy make resolving historical relationships of isolates, even within lineages, problematic (Farrer et al. 2013). Because of this, it is questionable if the relationship between invasive amphibian hosts and history of Bd invasion can ever be clearly elucidated.

Nevertheless, introducing infected hosts of any kind to naïve amphibian communities increases host density, elevating transmission rates (Rachowicz and Vredenburg 2004), and prevalence of infection which may be vectored into susceptible species. The American bullfrog is a good candidate to fulfil this role: it has been globally introduced (review in Ficetola et al. 2007) and carries Bd in native (Ouellet et al. 2005) and introduced populations 
1 in Asia (Bai et al. 2010), Europe (Garner et al. 2006), North (Peterson and McKenzie 2014)

2 and South America (Hanselman et al. 2004; Schloegel et al. 2010). Direct evidence of the

3 role of bullfrog as a reservoir of local Bd lineages and/or introduction of allopatric lineages to

4 native amphibian communities are lacking, but in Colorado, amphibian communities invaded

5 by non-native bullfrogs were more likely to support $\mathrm{Bd}$ infected individuals (Peterson and

6 McKenzie 2014). The transmission of Bd from native American bullfrog juveniles to

7 syntopic wood frog tadpoles (Lithobates sylvaticus) was shown experimentally by Greenspan

8 et al. (2012). Extending on their work, our experiment shows that infected and non-native

9 bullfrog tadpoles can transmit Bd to adult alpine newts under experimental conditions. Newts 10 exposed to infected bullfrog tadpoles in our study readily developed infections in a matter of 
1 In nature newts commonly leave water and stay on land for significant periods of time.

2 Behavioural avoidance of aquatic zoospores has been described in another species (e.g.

3 McMahon et al. 2014) and our experiment offered no opportunity for newts to escape from

4 the water. The aquatic environment is important for transmission of zoospores, and the heavy

5 infections consistently generated in our study by cohousing with bullfrog tadpoles were of

6 similar strength to burdens estimated from newts captured from aquatic environments in the

7 wild at sites where newts occur at high densities (Garner et al. 2005). Bullfrogs have not been

8 detected at the newt study sites sampled by Garner et al. (2005) and mortality of alpine newts

9 attributable to chytridiomycosis has never been reported. The impact of host community

10 structure on probability of infection and strength of infection with Bd is a common theme in infections is expected to elicit greater prevalence and heavier infections (Searle et al. 2011; but see Bielby et al. 2015). Infections of tadpoles were far stronger than newts in our study, which may go some way towards explaining why experimental newts experienced significant mortality while newts occupying ponds lacking a heterospecific reservoir exhibiting stronger infections appear not to. Further study of the relationships between habitat choice, host community composition and susceptibility of alpine newts to infection and chytridiomycosis is certainly warranted.

Some newts that died did not exhibit detectable infection using either diagnostic.

Several studies have reported increased risk of mortality during prolonged exposure to Bd even with no evidence of infection at time of death (Luquet et al. 2012; Garner et al. 2009). Resisting infection with $\mathrm{Bd}$ is probably costly, potentially increasing the mortality risk of these individuals. But not in all cases: of the four survivors, at least 3 exhibited significant levels of infection. One hypothesis for this could be inter-individual variation in immune defence. Innate immunity in the form of skin antimicrobial peptides secretions can act as first 
1 line of defence against $\mathrm{Bd}$, and has been shown to allow tolerance of infection (Woodhams et

2 al. 2007; Rollins-Smith 2009; Ramsey et al. 2010). Whatever component of immunity may be

3 responsible for tolerance or resistance, repeated exposure to $\mathrm{Bd}$ has been shown immunize

4 against subsequent costs (McMahon et al. 2014, but see Cashings et al. 2013. This seems

5 unlikely in our case as we have never detected infection in the source population for the

6 newts we used (102 adults tested with qPCR, C. Miaud, unpublished data) and none of our

7 experimental animals tested positive before exposure. These are strong indications that the

8 alpine newts used in the experiment were Bd naïve.

These experimental findings are the first evidence of death attributable to exposure to and infection with Bd in alpine newts, adding to an ever-growing list of European amphibian species that may be deleteriously affected through interactions with this fungus (Baláž et al. 2014; Bosch et al. 2013; Garner et al. 2013; Luquet et al. 2012; Bielby et al. 2009; Garner et al. 2009; Bosch et al. 2001). Additional surveillance for Bd-related newt mortality in the wild is called for to investigate potential disease-associated decline under natural conditions.

\section{Conclusion}

We conclude from our experiment that invasive bullfrogs are effective reservoirs of $\mathrm{Bd}$, capable of transmitting infections to native hosts. Infections with the Bd-GPL lineage transmitted by invasive bullfrogs can be sustained for weeks after initial exposure and have the capacity to cause significant mortality in native species. Although we cannot resolve the debate regarding the role invasive hosts have played in introducing $\mathrm{Bd}$ to Europe, we do conclude that infected, invasive bullfrog tadpoles will increase the likelihood that infection with Bd will be maintained in a European amphibian community (Spitzen-van der Sluijs et al. 2014). Experimental results (this study) do not always reflect field conditions, but spill-over 
1 from bullfrog tadpoles to native European amphibians has the potential to drive mortality in

2 native species. Removal of invasive bullfrogs as a conservation strategy has been adopted in

3 several European countries based on the conclusion that bullfrogs can cause native species

4 declines due to competition and predation (Kupferberg 1997; Lawler et al. 1999). Our study

5 further justifies these efforts. Even if removal may not eliminate infections in native hosts,

6 any reduction in density of infected hosts capable of transmitting to susceptible hosts should

7 reduce the likelihood of infections reaching potentially lethal thresholds (Peterson and

8 McKenzie 2014). Exposure duration, zoospore load and virulence can dictate the severity of

9 the costs associated with exposure and infection (e.g. Briggs et al. 2010) and the removal of 10 infected bullfrogs has a strong likelihood of reducing the impact of $\mathrm{Bd}$ on other, native susceptible host species.

Summary statement All experimental work done here was ethically reviewed at Université de Savoie-Mont-Blanc, and supported by the former president of the scientific committee M. L. Foulloy. Authorization to catch Alpine newts was provided by the regional authorities (DREAL Rhône-Alpes, permit N²009-10). CM, TD, AM, NCGG and AV were supported by ANR through the EU BiodivERsA-funded project R.A.C.E. (Risk Assessment of Chytridiomycosis to European amphibian biodiversity, M. Fisher coordinator), TWJG was supported by a NERC (grant NE/G002193/1) through the EU BiodivERsA-funded project R.A.C.E., but is currently supported for research on chytridiomycosis by NERC standard grant NE/K012509/1. KS was hosted in France thanks to the Office Franco-Québéquois pour la Jeunesse, programme Formation \& Emploi. The authors declare that they have no conflict of interest: none of the authors of this paper has a financial or personal relationship with other people or organizations that could inappropriately influence or bias the content of the paper. 


\section{References}

2

Bai C, Garner TWJ, Yiming L (2010) First evidence of Batrachochytrium dendrobatidis in China: discovery of chytridiomycosis in introduced American bullfrogs and native amphibians in the Yunnan Province, China. Ecohealth 7: 127-134

Baláž V, Vörös J, Civiš P, Voja J, Hettyey A, Sós E, Dankovics R, Jehle R, Christiansen DG, Clare F, Fisher MC, Garner TWJ, Bielby J (2014) Assessing risk and guidance on monitoring of Batrachochytrium dendrobatidis in Europe through identification of taxonomic selectivity of infection. Conserv Biol 28: 213-223

Bataille A, Fong JJ, Cha M, Wogan GOU, Baek HJ, Lee H, Min M-S, Waldman B (2013) Genetic evidence for a high diversity and wide distribution of endemic strains of the pathogenic chytrid fungus Batrachochytrium dendrobatidis in wild Asian amphibians. Mol Ecol 22: 4196-4209

Bielby J, Bovero S, Sotgiu G, Tessa G, Favelli M, Angelini C, Doglio S, Clare F, Gazzaniga E, Lapietra F, Garner TWJ (2009) Fatal chytridiomycosis in the Tyrrhenian painted frog. Ecohealth 6: 27-32

Bielby J, Bovero S, Sotgiu G, Tessa G, Favelli M, Angelini C, Perkins M, Garner TWJ (2013) Geographic, taxonomic and ecological variation in Batrachochytrium dendrobatidis infection within a highly endemic amphibian community. Divers \& Distrib 19: 1153-1163

Bielby J, Fisher MC, Clare FC, Rosa GM, Garner TWJ (2015) Host species vary in infection probability, sub-lethal effects, and costs of immune response when exposed to an amphibian parasite. Sci. Reports 5: 20828

Bosch J, Garcia D, Fernandez-Beaskoetxea S, Fisher MC, Garner TWJ (2013) Evidence for the introduction of lethal chytridiomycosis affecting wild Betic midwife toads (Alytes dickhilleni). Ecohealth 10: 82-89

Bosch J, Martínez-Solano I, Garcia-Paris M (2001) Evidence of a chytrid fungus infection involved in the decline of the common midwife toad (Alytes obstetricans) in protected areas of central Spain. Biol Conserv 97: 331-337 
1 Boyle DG, Boyle DB, Olson V, Morgan JAT, Hyatt AD (2004) Rapid quantitative detection

2

3

4

5

6 7 of chytridiomycosis (Batrachochytrium dendrobatidis) in amphibian samples using real-time Taqman PCR assay. Dis Aquat Organ 60: 141-148

Briggs CJ, Knapp RA, Vredenburg VT (2010) Enzootic and epizootic dynamics of the chytrid fungal pathogen of amphibians. Proc Nat Acad Sc U.S.A. 107: 9695-9700

Bürgi LP, Mills NJ (2014) Lack of enemy release for an invasive leafroller in California: temporal patterns and influence of host plant origin. Biol Inv 16: 1021-1034

Cashins SD, Grogan LF, McFadden M, Hunter D, Harlow PS, Berger L, et al. (2013) Prior Infection Does Not Improve Survival against the Amphibian Disease Chytridiomycosis. PLoS ONE 8(2): e56747.

Colautti R, Ricciardi A, Grigorovich IA, MacIsaac HJ (2004) Is invasion success explained by the enemy release hypothesis? Ecol Lett 7(8): 721-733

Crowl TT, Crist TO, Parmenter RR, Belovsky G, Lugo AE (2008) The spread of invasive species and infectious disease as drivers of ecosystem change. Frontiers in Ecology and the Environment 6(5): 238-246

Daszak P, Cunningham AA, Hyatt AD (2000) Emerging infectious diseases of wildlife threats to biodiversity and human health. Science 287: 443-449

Doddington BJ, Bosch J, Oliver JA, Grassly NC, Garcia G, Garner TWJ, Fisher MC (2013) Context-dependent amphibian host population response to an invading pathogen. Ecology 94: 1795-1804

Farrer RA, Henk DA, Garner TWJ, Balloux F, Woodhams DC, Fisher MC (2013)

Chromosomal copy number variation, selection and uneven rates of recombination reveal cryptic genome diversity linked to pathogenicity. PLoS Genetics 9(8): e1003703

Farrer RA, Weinert LA, Bielby J, Garner TWJ, Balloux F, Clare F, Bosch J, Cunningham AA, Weldon C, du Preez LH, Anderson L, Kosakovsky Pond SL, Shahar-Golan R, Henk DA, Fisher MC (2011) Multiple emergences of amphibian chytridiomycosis 
include a globalised hypervirulent recombinant lineage. Proc Nat Acad Sc U.S.A. 108: $18732-18736$

Ficetola GF, Bonin A, Miaud C (2008) Population genetics reveals origin and number of founders in a biological invasion. Mol Ecol 17: 773-782

Ficetola GF, Coïc C, Detaint M, Berroneau M, Lorvelec O, Miaud C (2007) Pattern of distribution of the American bullfrog Rana catesbiana in Europe. Biol Inv 9: 767-772

MC, TWJ. Garner (2007) The relationship between the emergence of Batrachochytrium dendrobatidis, the international trade in amphibians and introduced amphibian species. Fungal biology reviews 21: $2-9$

Garner TWJ, Walker S, Bosch J, Hyatt AD, Cunningham AA, Fisher MJ (2005) Chytrid fungus in Europe. Emerg. Infect. Dis. 11: 1639-1641

Garner TWJ, Perkins M, Govindarajulu P, Seglie D, Walker SJ, Cunningham AA, Fisher MC (2006) The emerging amphibian pathogen Batrachochytrium dendrobatidis globally infects introduced populations of the North American bullfrog, Rana catesbeiana. Biol Letters 2: 455-459

Garner TWJ, Walker S, Bosch J, Leech S, Rowcliffe JM, Cunningham AA, Fisher MC (2009) Life history trade-offs influence mortality associated with the amphibian pathogen Batrachochytrium dendrobatidis. Oikos 118: 783-791

Garner TWJ, Martel A, Bielby J, Bosch J, Anderson L, Meredith A, Cunningham AA, Fisher MC, Henk DA, Pasmans F (2013) Infectious diseases that may threaten Europe's amphibians. Pp. 1-41 In: Amphibian Biology, Volume 11, Issue 3: Diseases, Declines and Conservation of Amphibians in Seven Western European Countries. Pelagic Publishing Ltd.

Gervasi SS, Urbina J, Hua J, Chestnut T, Relyea RA, Blaustein AR (2013) Experimental evidence for American bullfrog (Lithobates catesbeianus) susceptibility to chytrid fungus (Batrachochytrium dendrobatidis). Ecohealth 10: 166-171

Gosner KL (1960) A simplified table for staging anuran embryos and larvae with notes on identification. Herpetol 16: 183-190

Greenspan SE, Calhoun AJ, Longcore JE, Levy MG (2012) Transmission of Batrachochytrium dendrobatidis to wood frogs (Lithobates sylvaticus) via a bullfrog (L. catesbeianus) vector. J Wild Diseases 48: 575-582 
1 Hanselmann R, Rodríguez A, Lampo M, Fajardo-Ramos L, Aguirre AA, Kilpatrick AM, Rodríguez JP, Daszak P (2004) Presence of an emerging pathogen of amphibians in introduced bullfrogs Rana catesbeiana in Venezuela. Biol Conserv 120: 115-119

Heger T, Jeschke JM (2014) The enemy release hypothesis as a hierarchy of hypotheses. Oikos 123: 741-750

Kupferberg SJ (1997) Bullfrog (Rana catesbeiana) invasion of a California river: the role of larval competition. Ecology 78: 1736-1751

Lawler SP, Dritz D, Strange T, Holyoak M (1999) Effects of introduced mosquitofish and bullfrogs on the threatened California red-legged frog. Conserv Biol 13: 613-622

Luquet E, Garner TWJ, Léna J-P, Bruel C, Joly P, Lengagne T, Grolet O, Plénet S (2012) Genetic erosion in wild populations makes resistance to a pathogen more costly. Evolution 66: 1942-1952

Martel A, Blooi M, Adriaensen C, Van Rooij P, Beukema W, Fisher MC, Farrer RA, Schmidt BR, Tobler U, Goka K, Lips KR, Muletz C, Zamudio K, Bosch J, Lötters S, Wombwell E, Garner TWJ, Spitzen-van der Sluijs A, Salvidio S, Ducatelle R, Nishikawa K, Nguyen TT, Van Bocxlaer I, Bossuyt F, Pasmans F (2014) Recent introduction of a chytrid fungus endangers Western Palearctic salamanders. Science 346: 630-631

McMahon TA, Sears BF, Venesky MD, Bessler SM, Brown JM, Deutsch K, Halstead NT, Lentz G, Tenouri N, Young S, Civitello DJ, Ortega N, Fites JS, Reinert LK, RollinsSmith LA, Raffel TR, Rohr JR (2014) Amphibians acquire resistance to live and dead fungus overcoming fungal immunosuppression. Nature 511:224-227

Michelin G, Epain-Henry C, Beguin D (2004) Grenouille taureau Lithobates catesbeianus (Shaw, 1802) Bilan des prospections et phase opérationnelle 2014. Comité Départemental de la Protection de la Nature et de l'Environnement, Syndicat d'Entretien du Bassin du Beuvron (Eds), 54 p.

Murray KA, Skerratt LF, Speare R, Callum HMC (2009) Impact and Dynamics of Disease in Species Threatened by the Amphibian Chytrid Fungus, Batrachochytrium dendrobatidis. Conserv Biol 23: 1242-1252 
1 Olson DH, Aanensen DM, Ronnenberg KL, Powell CI, Walker SF, Bielby J, Garner TWJ, Weaver G, the $B d$ Mapping Group, Fisher MC (2013) Mapping the global emergence of Batrachochytrium dendrobatidis, the amphibian chytrid fungus. PloS ONE 8(2): e56802

Ouellet, M., Mikaelian I, Pauli BD, Rodrigue J, Green DM (2005) Historical evidence of widespread chytrid infection in North American amphibian populations. Conserv Biol 19:1431-1440

Pasmans F, Van Rooij P, Blooi M, Tessa G, Bogaerts S, Sotgiu G, Garner TWJ, Fisher MC, Woeltjes T, Beukema W, Bovero S, Adriaensen C, Oneto F, Ottonello D, Martel A, Salvidio S (2013) Resistance to Chytridiomycosis in the European Plethodontid of the Genus Speleomantes. PloS ONE 8(5): e63639

Peterson AC, McKenzie VJ (2014) Investigating Differences across Host Species and Scales to Explain the Distribution of the Amphibian Pathogen Batrachochytrium dendrobatidis. PLoS ONE 9(9): e107441.

Prenter J, MacNeil C, Dick JTA, Dunn AM (2004) Roles of parasites in animal invasions. Trends in Ecology and Evolution 19(7): 385-390.

Rachowicz LJ, Vredenburg VT (2004) Transmission of Batrachochytrium dendrobatidis within and between amphibian life stages. Dis Aquat Organ 61: 75-83

Ramsey JP, Reinert LK, Harper LK, Woodhams DC, Rollins-Smith LA (2010) Immune defenses against Batrachochytrium dendrobatidis, a fungus linked to global amphibian declines, in the South African Clawed Frog, Xenopus laevis. Infect Immun 78:3981-3992

R Development Core team (2010) R: A language and environment for statistical computing. Vienna, Austria

Rollins-Smith LA (2009) The role of amphibian antimicrobial peptides in protection of amphibians from pathogens linked to global amphibian declines. Biochim Biophys Acta 1788:1593-1599

Richardson JML, Govindarajulu P, Anholt BR (2014) Distribution of the disease pathogen Batrachochytrium dendrobatidis in non-epidemic amphibian communities in western Canada. Ecography 37: 883-893 
1 Schloegel LM, Ferreira CM, James TY, Hipolito M, Longcore JE, Hyatt AD, Yabsley M, Martins AMCRPF, Mazzoni R, Davies AJ, P. Daszak (2010) The North American bullfrog as a reservoir for the spread of Batrachochytrium dendrobatidis in Brazil. Anim Conserv 13: 53-61

Schloegel LM, Picco AM, Kilpatrick AM, Davies AJ, Hyatt AD, Daszak P (2009) Magnitude of the US trade in amphibians and the presence of Batrachochytrium dendrobatidis and ranavirus infection in imported North American bullfrogs (Rana catesbeiana). Biol Conserv 142: 1420-1426

Searle CL, Biga L, Spatafora JW, Blaustein AR (2011) A dilution effect in the emerging amphibian pathogen Batrachochytrium dendrobatidis. Proc. Natl. Acad. Sci. U.S.A. 108: $16322-16326$

Spitzen - van der Sluijs A, Martel A, Hallmann CA, Bosman W, Garner TWJ, van Rooij P, Jooris R, Haesebrouck F, Pasmans F (2014) Environmental determinants promote recent endemism of Batrachochytrium dendrobatidis infections in amphibian assemblages in Northwestern Europe in the absence of disease outbreak. Conserv Biol 28: 1302-1311

Sztatecsny M, Glaser F (2011) From the eastern lowlands to the western mountains: first records of the chytrid fungus Batrachochytrium dendrobatidis in wild amphibian populations from Austria. Herpetol J 21: 87-90

Torchin ME, Lafferty KD, Dobson AP, McKenzie VJ, Kuris AM (2003) Introduced species and their missing parasites. Nature 421: 628-630

Walker SF, Bosch J, Gomez V, Garner TWJ, Cunningham AA, Schmeller DS, Ninyerola M, Henk D, Ginestet C, Christian-Philippe A, Fisher MC (2010) Factors driving pathogenicity versus prevalence of the amphibian pathogen Batrachochytrium dendrobatidis and chytridiomycosis in Iberia. Ecol Letters 13: 372-382

Walker SF, Bosch J, James TY, Litvintseva AP, Valls JAO, Piña S, Garcia G, Rosa GA, Cunningham AA, Hole S, Griffiths R, Fisher MC (2008) Invasive pathogens threaten species recovery programs. Current Biol 18: R853-R854

Wolfe LM, Elzinga JA, Biere A (2004) Increased susceptibility to enemies following introduction in the invasive plant Silene latifolia. Ecol Letters 7: 813-820 
1 Woodhams DC, Ardipradja K, Alford RA, Marantelli G, Reinert LK, Rollins-Smith LA 2 (2007) Resistance to chytridiomycosis varies among amphibian species and is correlated with skin peptide defenses. Anim Conserv 10:409-417

4 Zampiglia M, Canestrelli D, Chiocchio A, Nascetti G (2013) Geographic distribution of the $5 \quad$ chytrid pathogen Batrachochytrium dendrobatidis among mountain amphibians along 6 the Italian peninsula. Dis Aquat Organ 107: 61-68 
Fig. 1. Survival curves for American bullfrog tadpoles Lithobates catesbeianus tadpoles (a) and alpine newt Ichthyosaura alpestris (b). For both figures, animals housed singly and not exposed to the fungus Batrachochytrium dendrobatidis $(\mathrm{Bd})$ are represented by the dotted line, animals cohoused with uninfected animals are represented by the solid line and cohoused animals where tadpoles were infected with Bd are represented by broken line.

Fig. 1a

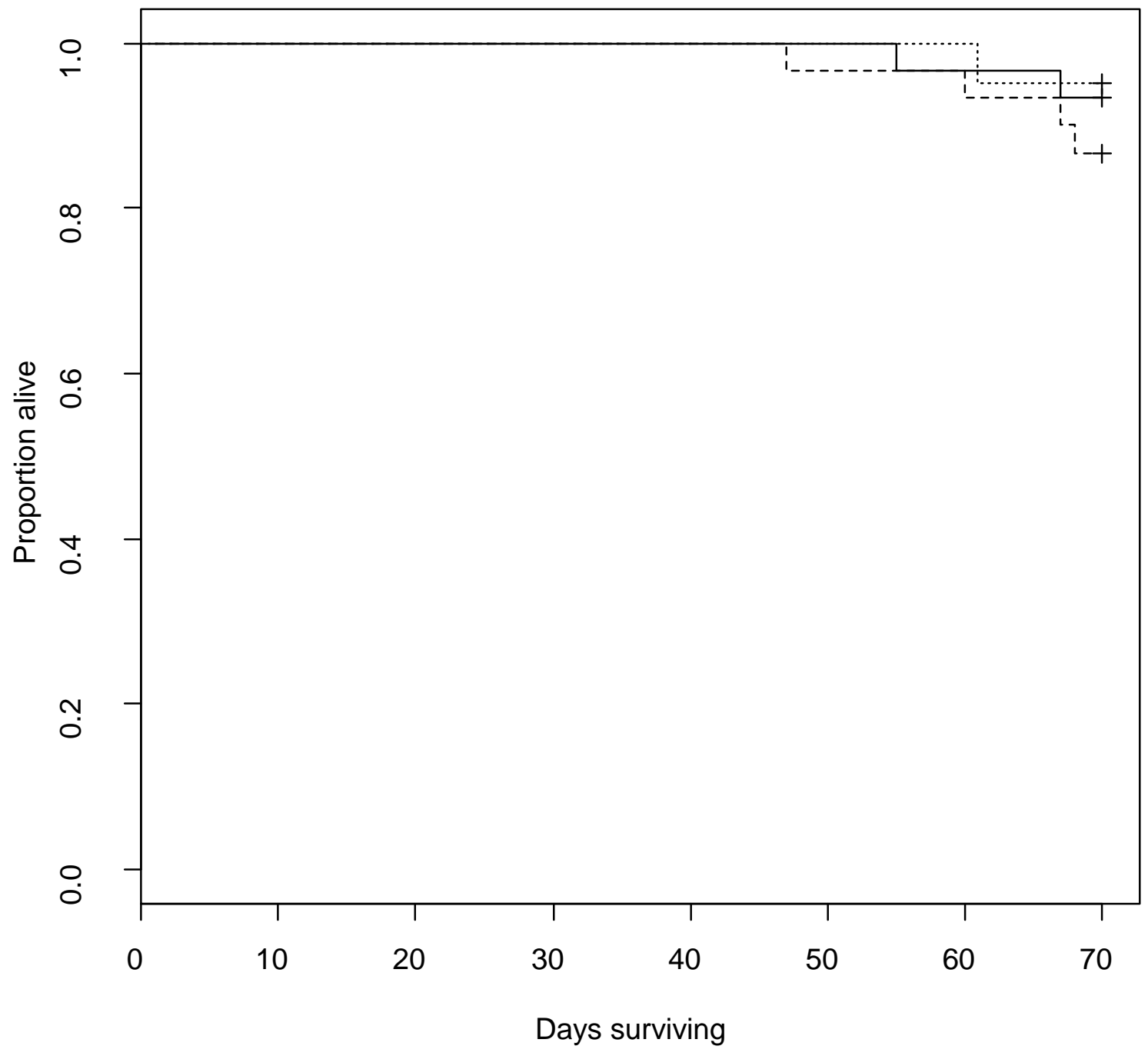


Fig. 1b

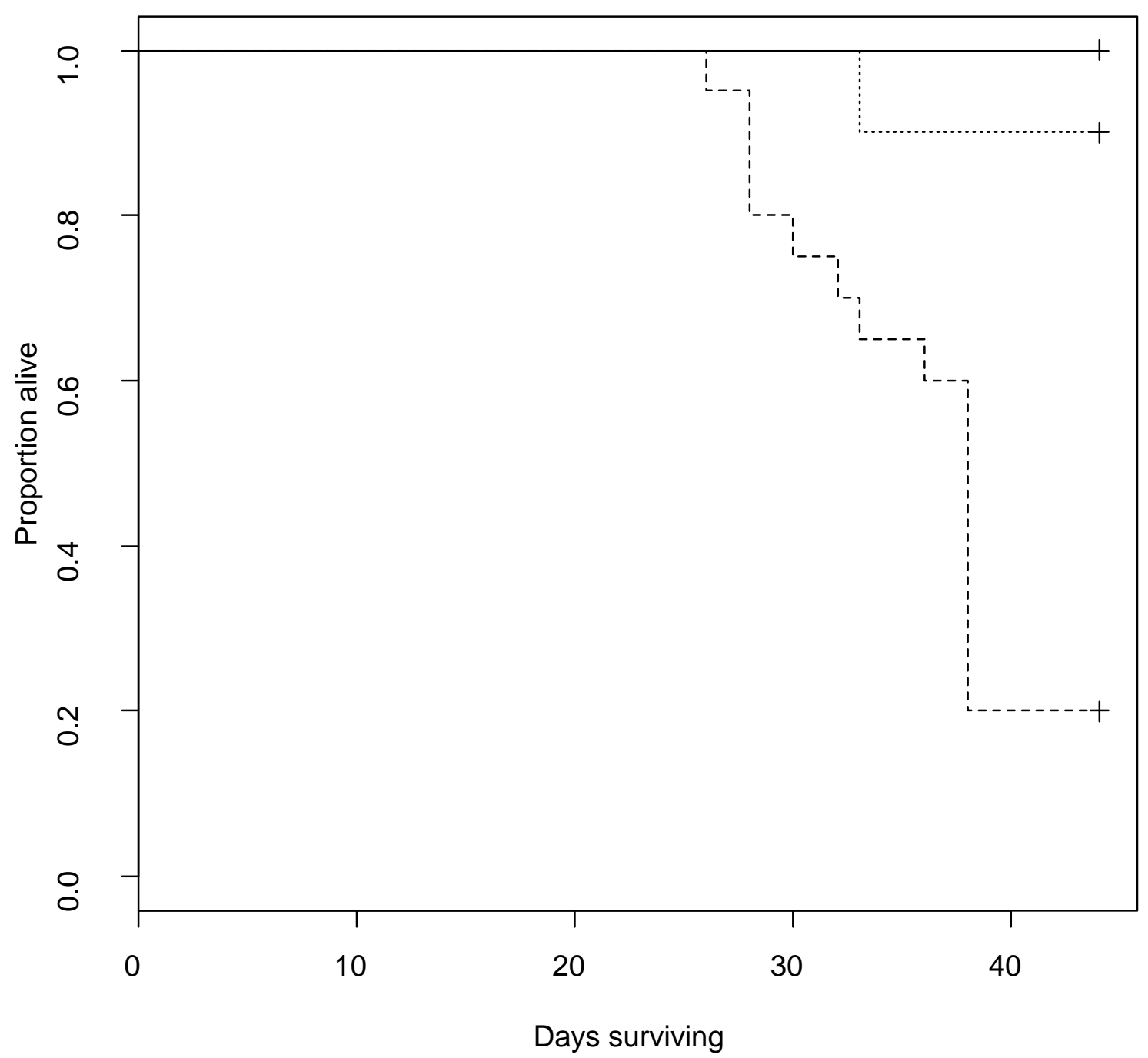


Table 1 Design and results of the cross contamination experiment, the co-housing of alpine newt Ichthyosaura alpestris with American bullfrog tadpoles Lithobates catesbeianus infected by the fungus Batrachochytrium dendrobatidis.

\section{qPCR test}

Before the experiment

$\mathrm{Bd}+\quad$ Bd-

Alpine newts alone $(\mathrm{n}=40)$

Bullfrog tadpoles alone $(\mathrm{n}=20)$

$0 \quad 40$

Bullfrog tadpoles $\mathrm{Bd}+(\mathrm{n}=60)$

020

Bullfrog tadpoles Bd- $(n=30)$

$60 \quad 0$

$0 \quad 30$

During the experiment

Alpine newt alone $(\mathrm{n}=10)$

qPCR test

st

Alpine newt with Bd- tadpoles $(\mathrm{n}=10)$

$\mathrm{Bd}+\quad \mathrm{Bd}-$

Histological test

Alpine newts with $\mathrm{Bd}+$ tadpoles $(\mathrm{n}=20)$ overall

$0 \quad 10$

$0 \quad 10$

Alpine newts with $\mathrm{Bd}+$ tadpoles which died $(\mathrm{n}=16)$

Alpine newts with $\mathrm{Bd}+$ tadpoles which survived $(\mathrm{n}=4)$

$14 \quad 6$

6

115

$3 \quad 1$

$\mathrm{Bd}+$

Bd-

Bullfrog tadpoles $\mathrm{Bd}+=$ tadpole experimentally infected with Bd and co-housed with alpine newts. Bullfrog tadpoles Bd- = tadpole Bd- and cohoused with alpine newts. Alpine newt with $\mathrm{Bd}$ - or $\mathrm{Bd}+$ tadpoles $=1$ alpine newt adult is co-housed with 3 American Bullfrog tadpoles. 
Table 2 Survival of alpine newts Ichthyosaura alpestris co-housed with American bullfrog tadpoles Lithobates catesbeianus infected by the fungus Batrachochytrium dendrobatidis.

\begin{tabular}{|c|c|c|c|c|c|c|}
\hline \multicolumn{7}{|c|}{ Treatment $=$ newts with $\mathrm{Bd}$ positive tadpoles } \\
\hline Time & $\mathrm{n}$ & $\mathrm{n}$ death & survival & std.err & \multicolumn{2}{|c|}{ lower $95 \% \mathrm{CI}$ upper $95 \% \mathrm{CI}$} \\
\hline 26 & 20 & 1 & 0.95 & 0.0487 & 0.8591 & 1.000 \\
\hline 28 & 19 & 3 & 0.80 & 0.0894 & 0.6426 & 0.996 \\
\hline 30 & 16 & 1 & 0.75 & 0.0968 & 0.5823 & 0.966 \\
\hline 32 & 15 & 1 & 0.70 & 0.1025 & 0.5254 & 0.933 \\
\hline 33 & 14 & 1 & 0.65 & 0.1067 & 0.4712 & 0.897 \\
\hline 36 & 13 & 1 & 0.60 & 0.1095 & 0.4195 & 0.858 \\
\hline 38 & 12 & 8 & 0.20 & 0.0894 & 0.0832 & 0.481 \\
\hline \multicolumn{7}{|c|}{12 dead in this treatment } \\
\hline \multicolumn{7}{|c|}{ Treatment $=$ newt as control (newt alone) } \\
\hline Time & $\mathrm{n}$ & $\mathrm{n}$ death & survival & std.err & \multicolumn{2}{|c|}{ lower $95 \%$ CI upper $95 \% \mathrm{CI}$} \\
\hline 30 & 10 & 0 & 1.0 & - & - & - \\
\hline 33 & 10 & 1.0 & 0.90 & 0.0949 & 0.7320 & 1.0000 \\
\hline 38 & 10 & 1.0 & 0.9 & 0.0949 & 0.7320 & 1.0000 \\
\hline 1 dead & con & day 33 & & & & \\
\hline
\end{tabular}

Time $=$ days since the beginning of the experiment, $\mathrm{n}=$ number of alive alpine newts, $\mathrm{n}$ death $=$ number of dead alpine newt along the last $24 \mathrm{~h}$. 